УДК 796.012.23-053.6

DOI https://doi.org/10.26661/2663-5925-2020-1-09

\title{
ДИНАМІКА ЗБЕРЕЖЕННЯ ГНУЧКОСТІ В ПІДЛІТКІВ СЕРЕДНЬОГО ШКІЛЬНОГО ВІКУ
}

\author{
Чиженок Т. М. \\ кандидат біологічних наук, \\ дочент кафедри теорії та методики фізичної культури і спорту \\ Запорізький національний університет \\ вул. Жуковського, 66, Запоріжжя, Україна \\ orcid.org/0000-0001-6687-2643 \\ chijiktoma@gmail.com \\ Коваленко Ю. О. \\ кандидат педагогічних наук, \\ доцент кафедри теорії та методики фізичної культури і спорту \\ Запорізький національний університет \\ вул. Жуковського, 66, Запоріжжя, Украӥна \\ orcid.org/0000-0002-0827-9371 \\ visnik_znu@ukr.net
}

\begin{abstract}
Ключові слова: гнучкість, рухливість хребта, рівень гнучкості, уроки фізичної культури, засоби виховання гнучкості, хлопчики, середній шкільний вік.
\end{abstract}

Під час теоретичного аналізу проблеми встановлено, що середній шкільний вік - важливий період удосконалення основних функцій організму засобами фізичного виховання, у цьому віці потрібно забезпечити такий ступінь усебічного розвитку, який дав би змогу оволодіти досконалими формами основних життєво необхідних рухів та високою результативністю проявляти основні рухові здібності - силу, швидкість витривалість, координаційні здібності, гнучкість. Недостатня гнучкість призводить до порушення постави, виникнення остеохондрозу, змін у ходьбі. Низький рівень розвитку гнучкості може бути причиною травм і недосконалої техніки. Відомий факт, що гнучкість $€$ одним із найважливіших показників здоров'я. Вона служить базою для розвитку інших фізичних якостей і $є$ основою успішного оволодіння будь-якою фізичною вправою. Особливо це актуально в молодшому та середньому шкільному віці. Було проведено експеримент, сутність якого полягала в тому, що три експериментальні групи хлопчиків (експериментальна група № 1, експериментальна група № 2 та експериментальна група № 3) виконували вправи на розвиток гнучкості протягом семи тижнів в основній частині уроку. Вправи виконувались у повільному темпі з інтервалом відпочинку між серіями 1-2 хв, 3 умовою досягнення максимальної амплітуди рухів у кожному повторенні. Потім вивчалася динаміка показників гнучкості школярів після припинення застосування вправ, спрямованих на підвищення рухливості хребта. Отримані під час дослідження дані надають учителю інформацію про належний стан рівня розвитку гнучкості після припинення виконання вправ, спрямованих на розвиток рухливості в суглобах хребтового стовпа. Встановлено, що показники гнучкості хлопчиків віком 11-13 років в експериментальних групах 2 та 3 підтверджено ефективністю дворазових і триразових занять порівняно 3 одноразовими. Спостережено та зафіксовано, що досягнутий рівень гнучкості хлопчиків віком 11 років був більш стійким. Це доводить, що цей вік є критичним у розвитку гнучкості. Після припинення занять, спрямованих на розвиток гнучкості, стабілізації показників рухливості суглобів не відбувалося ні в одній з експериментальних груп, що загалом збігається з даними літератури. 


\title{
DYNAMICS OF FLEXIBILITY CONSERVATION IN TEENAGERS OF MIDDLE SCHOOL AGE
}

\author{
Chizhenok T. M. \\ PhD (Biological), \\ Assistant Professor at the Department of Theory and Methods of Physical Culture and Sports \\ Zaporizhzhia National University \\ Zhukovsky str., 66, Zaporizhzhia, Ukraine \\ orcid.org/0000-0001-6687-2643 \\ chijiktoma@gmail.com \\ Kovalenko Yu. O. \\ PhD (Pedagogy), \\ Assistant Professor at the Department of Theory and Methods of Physical Culture and Sports \\ Zaporizhzhia National University \\ Zhukovskogo str., 66, Zaporizhzhia, Ukraine \\ orcid.org/0000-0002-0827-9371 \\ visnik_znu@ukr.net
}

Key words: flexibility, spinal mobility, level of flexibility, physical education lessons, means of raising flexibility, boys, secondary school age.
In the course of the theoretical analysis of the problem, it was established that middle school age is an important period of improving the basic functions of the body by means of physical education, at this age it is necessary to provide such a degree of all-round development that would allow mastering the perfect forms of the basic vital movements and high efficiency to show the basic motor abilities - strength, speed, endurance, coordination abilities, flexibility. Low level of flexibility leads to posture disorders, osteochondrosis, leads to changes in walking. It is a well-known fact that flexibility is one of the most important indicators of health. It serves as the basis for the development of other physical qualities, and is the basis for the successful mastery of any physical exercise. This is especially true in primary and secondary school age. An experiment was carried out, the essence of which was that 3 experimental groups of boys (experimental group No. 1, experimental group No. 2 and experimental group No. 3) performed exercises for the development of flexibility for 7 weeks in the main part of the lesson. The exercises were performed at a slow pace with a rest interval of 1-2 min between series, with the condition that the maximum range of motion was achieved in each repetition. Then the dynamics of indicators of flexibility of schoolchildren was studied after the abolition of exercises aimed at increasing the mobility of the spine. The data obtained in the course of the study provide the teacher with information about the proper state of the level of development of flexibility after the termination of exercises aimed at developing mobility in the joints of the spinal column. It was found that the indicators of flexibility of boys aged 11-13 years in experimental groups 2 and 3 confirmed the effectiveness of double and triple training compared with one-time. It was noted and recorded that the achieved level of flexibility in boys at the age of 11 was more stable. This proves that this age is critical in the development of flexibility. After the termination of exercises aimed at the development of flexibility, stabilization of the indicators of joint mobility did not occur in any of the experimental groups, in general it coincides with the literature data. 
Постановка проблеми. Середній шкільний вік - важливий період удосконалення основних функцій організму засобами фізичного виховання, у цьому віці необхідно забезпечити такий ступінь усебічного розвитку, який дав би можливість оволодіти досконалими формами основних життєво необхідних рухів і високою результативністю проявляти основні рухові здібності - силу, швидкість витривалість, координаційні здібності, гнучкість. Якщо це завдання розв'язано, то надалі передбачається не поліпшення, а збереження на оптимальному рівні розвитку цих якостей $[1$, с. $86 ; 2$, с. 30$]$.

Гнучкість $є$ одним із найважливіших показників здоров'я. Вона служить базою для розвитку інших фізичних якостей і $\epsilon$ основою успішного оволодіння будь-якою фізичною вправою.

Гнучкість стимулює функції багатьох систем та органів, сприяє формуванню життєво необхідних рухових навичок і вихованню правильної постави $[1$, с. $87 ; 2$, с. $29 ; 3$, с. 73$]$.

Дані науково-методичної літератури і спортивної практики показують, що розвиток гнучкості у зрілому віці - складний і малоефективний процес, тоді як молодший і середній шкільний вік створює для цього сприятливі умови [3, с. 54; 4, с. 12].

3 огляду на те, що основною формою організації навчально-виховного процесу з фізичної культури в загальноосвітніх навчальних закладах $\epsilon$ урок, ефективність його великою мірою залежить від оптимізації використання фізичних навантажень. Однак для учнів, які мають надмірно високі показники гнучкості, часто потрібно обмежувати вправи на розтягування і застосовувати більш силові та загальнорозвивальні вправи для зміцнення опорно-рухового апарату. Водночас учням, у яких дуже обмежена рухомість у суглобах, потрібно виконувати спеціальні фізичні вправи, які забезпечать підвищення загального рівня гнучкості [3, с. 98 ; 4, с. 203 ; 5, с. 267].

Як правило, гнучкі діти, здатні виконувати рухи точніше, елегантніше краще засвоюють техніку координаційно-складних вправ.

Недостатня гнучкість призводить до порушення постави, виникнення остеохондрозу, зміни в ходьбі. Низький рівень розвитку може бути причиною травм і недосконалої техніки.

Недостатній розвиток гнучкості обмежує можливості вдосконалення якостей, призводить до зниження сили і швидкості, витривалості, збільшення м'язової енерговитрати та зниження економічної роботи.

Питання розвитку гнучкості та їі вікові зміни досить детально вивчалися вітчизняними і зарубіжними дослідниками $[4$, с. $156 ; 5$, с. 271]. Зокрема, у літературі досить грунтовно висвітлено проблеми розвитку гнучкості в дітей і підлітків шкільного віку.
У вітчизняній і зарубіжній літературі $€$ публікації, що присвячені вивченню динаміки гнучкості через обмеження, які сприяли розвитку гнучкості, особливо в тих, що займаються спортом. Було зазначено, що рівень гнучкості у спортсменів дуже знижується після двох тижнів припинення занять, які спрямовані на підвищення рухливості в суглобах $[6$, с. $82 ; 7$, с. 301$]$.

Мета статті. Мета дослідження - вивчення особливостей збереження гнучкості в підлітків середнього шкільного віку.

Досягнення поставленої мети здійснювалося шляхом розв'язання основних завдань дослідження. Відповідно до мети роботи розв'язувалися такі завдання: 1. Оцінити рівень гнучкості у хлопчиків віком 11-13 років на початку експерименту. 2. Виявити динаміку зміни в показниках гнучкості хлопчиків 11-13 років після припинення застосування вправ, спрямованих на підвищення рухливості хребта.

3 метою розв'язання поставлених завдань було використано такі методи дослідження: 1. Аналіз та узагальнення літературних джерел, який показав, що хоч про гнучкість і методику ії розвитку накопичено досить багато інформації, та все ж вона (особливо у фізкультурній практиці) певною мірою недооцінюється. На розвиток гнучкості часто дивляться як на щось додаткове, супутне розвитку таких важливих якостей, як сила, швидкість, витривалість.

Гнучкість - це раціональна праця м'язів, чим більша амплітуда рухів, тим легше людині рухатися. Гнучкість - властивість опорно-рухового апарату, що визначає межі руху ланок тіла.

Встановлено, що найліпше гнучкість розвинена в дітей: їхні зв'язки можуть подовжуватися на $6-10 \%$, тоді як у 40-річних людей - тільки на $4-5 \%$, а в $60-70-$ річних - на $1-3 \%$ [1, с. 88 ; 7 , с. $312 ; 8$, с. 335$]$.

Ні сила, ні витривалість, ні швидкість не знижуються 3 віком так сильно, як гнучкість. Добре розвинена гнучкість сприяє швидкому опануванню новими рухами та $є$ однією з умов успіху в таких видах рухів, як гімнастика, аеробіка, плавання, деякі легкоатлетичні вправи [9, с. 142].

2. Педагогічні спостереження з метою визначення й оцінки виконання вправ для розвитку гнучкості й рухливості в суглобах.

3. Вимірювання гнучкості хребтового стовпа проводили під час виконання нахилу уперед із положення сидячи, см. Тест виконували двічі.

4. Педагогічний експеримент.

Сутність педагогічного експерименту була в тому, що три експериментальні групи хлопчиків (експериментальна група № 1, експериментальна група № 2 та експериментальна група № 3) виконували вправи на розвиток гнучкості протягом 
семи тижнів в основній частині уроку. Вправи виконувались у повільному темпі 3 інтервалом відпочинку між серіями 1-2 хв, 3 умовою досягнення максимальної амплітуди рухів у кожному повторенні.

Фізичні вправи, які застосовували для гнучкості хребтового стовпа.

Вправи для хребтового стовпа: 1.3 різних в.п. основна стійка, стійка ноги нарізно; нахил уперед, у сторони, з різними рухами руками; нахил уперед із захопленням ніг; повороти тулуба; нахил у поєднанні $з$ поворотами тулуба; кругове обертання тулуба.

2. Нахил уперед: нахили із захопленням ніг.

3. 3 упору присівши, випрямлення ніг, не відриваючи рук від підлоги.

4. 3 різних вихідних положень: в.п., ноги нарізно, стоячи на колінах та інші; нахил назад.

5. «Міст» із положення, лежачи на спині.

6. Лежачи на животі, прогинаючись захопити руками стопи.

У хлопчиків першої експериментальної групи $\left(E \Gamma_{1}\right)$ розвиток гнучкості здійснювався один раз на тиждень, у другій експериментальній групі $\left(E \Gamma_{2}\right)$ - двічі на тиждень і в третій групі $\left(\mathrm{E} \Gamma_{3}\right)-$ відповідно на кожному уроці в підготовчої, основної та підсумкової частинах.

У кінці чверті вправи на розвиток гнучкості хлопчики трьох експериментальних груп віком від 11 до 13 років не виконували протягом семи тижнів із метою з'ясування динаміки збереження гнучкості.

На другому етапі дослідження (початок III чверті) було проведено перше тестування, а через чотири тижні - повторне тестування.

Оцінка динаміки досягнутого рівня гнучкості хребетного стовпа у хлопчиків 11-13 років після припинення застосування фізичних вправ, спрямованих на підвищення й підтримання рівня рухливості хребта здійснювалося завдяки порівнянню показників, отриманих на першому та другому етапах дослідження.

5. Методи математичної статистики: розрахунок середньої арифметичної величини (M); середнього квадратичного відхилення ( $\delta)$; помилки середнього арифметичного (m); коефіцієнта достовірності (t).

Дослідження проводилося на базі загальноосвітньої школи м. Запоріжжя.

У дослідженні взяли участь хлопчики віком від 11-13 років у кількості 81 підліток.

Вікова група 11-13 років обрана нами тому, що гнучкість найлегше розвивати в дитячому та підлітковому віці і планувати виховання гнучкості потрібно в період із 11 до 14 років.

Усі учнів за станом здоров'я було віднесено до основної медичної групи, вони мали середній рівень фізичного розвитку.
Для досягнення поставленої мети провели педагогічний експеримент, який мав два етапи.

На I етапі провели тестування 81 хлопчика 3 метою оцінки рівня розвитку показників рухливості хребта.

У результаті тестування було сформовано три експериментальні групи 3 низьким рівнем розвитку гнучкості в кількості: хлопчиків 11 років 31 особа, 12 років - 26 осіб і 13 років - 24 особи.

На II етапі провели повторне тестування 3 метою виявлення природного зниження гнучкості у хлопчиків 11-13 років після припинення застосування фізичних вправ, спрямованих на підвищення розвитку рухливості суглобів.

Виклад основного матеріалу. На початку експерименту вивчено рівень розвитку гнучкості у хлопчиків віком 11, 12, 13 років.

Аналіз показників гнучкості у хлопчиків віком 11 років показав, що протягом 1-7 тижнів в експериментальній групі № 1, яка виконувала вправи, спрямовані на розвиток гнучкості один раз на тиждень, спостерігалося коливання показників гнучкості в бік підвищення і в бік зниження від першого до сьомого тижня.

Наприклад, на початку першого тижня показник гнучкості в Е $\Gamma_{1}$ становив - $-1,9 \pm 0,04$ см, на

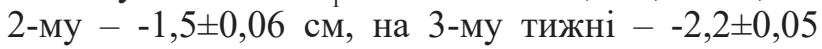
см. Між показниками було виявлено вірогідну різницю $(\mathrm{t}=5,7 ; \mathrm{t}=8,7)$ (табл. 1). Починаючи 3 3-го тижня показники гнучкості залишилися на одному рівні, а потім знову підвищувалися. Але отримані дані показників гнучкості у хлопчиків 11 років експериментальної групи № 1 залишилися на «низькому рівні» (табл. 1).

Під час аналізу показників гнучкості хлопчиків віком 11 років експериментальної групи № 2 (вправи виконували двічі на тиждень) стійке підвищення максимальних показників спостерігалося 3 5-го тижня занять.

Наприклад, показник гнучкості експериментальної групи № 2 дорівнював нульовій позначці на 5-му тижні занять, на 6-му - становив $+1,2 \pm 0,03$

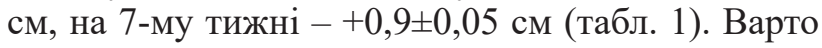
зазначити, що отримані показники гнучкості хлопчиків віком 11 років експериментальної групи № 2 теж відповідали «низькому рівню» розвитку.

В експериментальній групі № 3 (вправи виконували тричі на тиждень) у хлопчиків 11 років під час визначення гнучкості булл статистично вірогідні відмінності зафіксовано після 4-го тижня занять. Водночас ступінь рухливості в суглобах підвищився до «середнього рівня» нормативних значень, результат становив $+2,3 \pm 0,07$ см після 5-го тижня занять (табл. 1).

Між показниками гнучкості хлопчиків 11 років експериментальних груп № 1, 2, 3 було виявлено вірогідні відмінності починаючи 3 1-го до 
7-го тижня, за винятком показників гнучкості ЕГ та $\mathrm{E} \Gamma_{2}, \mathrm{E} \Gamma_{2}$ та $\mathrm{E} \Gamma_{3}$, отриманих після 5-го тижня занять (табл. 1).

Під час оцінювання гнучкості у віці 12 років в експериментальній групі № 1 (виконували вправи один раз на тиждень) та експериментальній групі № 2 (виконували вправи двічі на тиждень) в абсо- лютних показниках рухливості в суглобах хребта не спостерігалося (для 1-7-го тижня), вони були із знаком мінус (табл. 2).

В експериментальній групі № 3 хлопчиків віком 12 років (виконували вправи тричі на тиждень) під час визначення гнучкості збільшення максимальної амплітуди руху в суглобах хребта

Таблиця 1

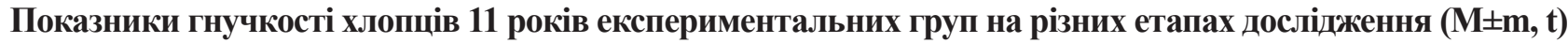

\begin{tabular}{|c|c|c|c|c|c|c|}
\hline \multirow[b]{2}{*}{ Етапи дослідження } & \multirow{2}{*}{$\begin{array}{c}\text { Експери- } \\
\text { ментальна } \\
\text { група № } 1 \\
\text { n=12 } \\
\end{array}$} & \multirow{2}{*}{$\begin{array}{c}\text { Експери- } \\
\text { ментальна } \\
\text { група № } 2 \\
\text { n=10 }\end{array}$} & \multirow{2}{*}{$\begin{array}{c}\text { Експери- } \\
\text { ментальна } \\
\text { група № } 3 \\
\text { n=9 }\end{array}$} & \multicolumn{3}{|c|}{ Достовірність розрізнень } \\
\hline & & & & $\mathrm{E} \Gamma_{1}-\mathbf{t}{ }_{1}$ & $\mathbf{E} \Gamma_{2}-\frac{\mathbf{t}_{2}}{-} \mathbf{E} \Gamma_{3}$ & $\mathbf{E} \Gamma_{1} \mathbf{t}_{3}-\mathbf{E} \Gamma_{3}$ \\
\hline \multirow{2}{*}{ Перший тиждень } & $-1,9 \pm 0,04$ & $-2,2 \pm 0,05$ & $-2,3 \pm 0,15$ & 5,0 & 0,62 & 2,5 \\
\hline & $\mathrm{t}=5,7$ & $t=3,3$ & $\mathrm{t}=1,0$ & & & \\
\hline \multirow{2}{*}{ Другий тиждень } & $-1,5 \pm 0,06$ & $-2,0 \pm 0,04$ & $-2,4 \pm 0,11$ & 7,2 & 3,6 & 7,5 \\
\hline & $\mathrm{t}=8,7$ & $\mathrm{t}=1,66$ & $\mathrm{t}=5,0$ & & & \\
\hline \multirow{2}{*}{ Третій тиждень } & $-2,2 \pm 0,05$ & $-1,9 \pm 0,04$ & $-3,0 \pm 0,06$ & 5,0 & 45,7 & 10,0 \\
\hline & $\mathrm{t}=1,45$ & $\mathrm{t}=22,55$ & $\mathrm{t}=38,3$ & & & \\
\hline \multirow{2}{*}{ Четвертий тиждень } & $-2,1 \pm 0,05$ & $-1,0 \pm 0,01$ & $+0,7 \pm 0,02$ & 22,0 & 0,06 & 28,0 \\
\hline & $t=7,5$ & $\mathrm{t}=0$ & $\mathrm{t}=22,8$ & & & \\
\hline \multirow{2}{*}{ П’ятий тиждень } & $-1,5 \pm 0,06$ & 0 & $+2,3 \pm 0,07$ & - & - & 8,8 \\
\hline & $\mathrm{t}=11,4$ & $\mathrm{t}=0$ & $\mathrm{t}=6,25$ & & & \\
\hline \multirow{2}{*}{ Шостий тиждень } & $-0,7 \pm 0,03$ & $+1,2 \pm 0,03$ & $+1,8 \pm 0,04$ & 12,5 & 12,0 & 22,0 \\
\hline & $\mathrm{t}=10,0$ & $\mathrm{t}=5,0$ & $\mathrm{t}=1,42$ & & & \\
\hline \multirow{2}{*}{ Сьомий тиждень } & $-1,4 \pm 0,05$ & $+0,9 \pm 0,05$ & $+1,7 \pm 0,06$ & 7,14 & 10,0 & 3,7 \\
\hline & $\mathrm{t}=10,0$ & $\mathrm{t}=16,0$ & $\mathrm{t}=1,43$ & & & \\
\hline \multirow{2}{*}{$\begin{array}{l}\text { Період канікул } \\
\text { (2 тижні) }\end{array}$} & $-2,0 \pm 0,03$ & $+0,1 \pm 0,01$ & $+1,5 \pm 0,04$ & 63,3 & 35,0 & 10,0 \\
\hline & $\mathrm{t}=26,0$ & $\mathrm{t}=47,5$ & $\mathrm{t}=10,0$ & & & \\
\hline Через 5 тижнів & $-0,7 \pm 0,04$ & $-2,0 \pm 0,04$ & $+0,9 \pm 0,05$ & 21,6 & 18,3 & 3,33 \\
\hline
\end{tabular}

Таблиця 2

Показники гнучкості хлопців 12 років експериментальних груп на різних етапах дослідження (M \pm m, t)

\begin{tabular}{|c|c|c|c|c|c|c|}
\hline \multirow[b]{2}{*}{ Етапи дослідження } & \multirow{2}{*}{$\begin{array}{c}\text { Експери- } \\
\text { ментальна } \\
\text { група № } 1 \\
\text { n=10 }\end{array}$} & \multirow{2}{*}{$\begin{array}{c}\text { Експери- } \\
\text { ментальна } \\
\text { група № } 2 \\
\text { n=7 }\end{array}$} & \multirow{2}{*}{$\begin{array}{c}\text { Експери- } \\
\text { ментальна } \\
\text { група № } 3 \\
\text { n=9 }\end{array}$} & \multicolumn{3}{|c|}{ Достовірність розрізнень } \\
\hline & & & & $\mathbf{E} \Gamma_{1} \stackrel{\mathbf{t}_{1}}{-} \mathbf{E} \Gamma_{2}$ & $\mathbf{E} \Gamma_{2} \stackrel{\mathbf{t}_{2}}{-} \mathbf{E} \Gamma_{3}$ & $\mathbf{E} \Gamma_{1} \stackrel{\mathbf{t}_{3}}{-} \mathbf{E} \Gamma_{3}$ \\
\hline \multirow{2}{*}{ Перший тиждень } & $-3,1 \pm 0,12$ & $-3,8 \pm 0,06$ & $-2,8 \pm 0,03$ & 5,38 & 14,2 & 2,5 \\
\hline & $\mathrm{t}=6,9$ & $\mathrm{t}=12,5$ & $\mathrm{t}=2,86$ & & & \\
\hline \multirow{2}{*}{ Другий тиждень } & $-4,0 \pm 0,05$ & $-4,8 \pm 0,05$ & $-3,0 \pm 0,06$ & 11,4 & 22,5 & 12,5 \\
\hline & $t=7,5$ & $\mathrm{t}=11,4$ & $\mathrm{t}=1,43$ & & & \\
\hline \multirow{2}{*}{ Третій тиждень } & $-3,1 \pm 0,11$ & $-4,0 \pm 0,05$ & $-2,9 \pm 0,04$ & 7,5 & 6,9 & 1,67 \\
\hline & $\mathrm{t}=5,0$ & $\mathrm{t}=17,1$ & $\mathrm{t}=36,6$ & & & \\
\hline \multirow{2}{*}{ Четвертий тиждень } & $-3,7 \pm 0,06$ & $-2,8 \pm 0,05$ & $-0,7 \pm 0,05$ & 11,2 & 30,0 & 37,5 \\
\hline & $\mathrm{t}=3,75$ & $\mathrm{t}=1,66$ & $\mathrm{t}=1,66$ & & & \\
\hline \multirow{2}{*}{ П’ятий тиждень } & $-4,0 \pm 0,05$ & $-2,9 \pm 0,04$ & $-0,8 \pm 0,04$ & 18,3 & 35,0 & 53,3 \\
\hline & $\mathrm{t}=11,1$ & $\mathrm{t}=1,66$ & $\mathrm{t}=5,0$ & & & \\
\hline \multirow{2}{*}{ Шостий тиждень } & $-3,0 \pm 0,08$ & $-2,8 \pm 0,05$ & $+0,5 \pm 0,04$ & 2,2 & 38,3 & 27,7 \\
\hline & $\mathrm{t}=10,2$ & $\mathrm{t}=1,23$ & $\mathrm{t}=4,0$ & & & \\
\hline \multirow{2}{*}{ Сьомий тиждень } & $-2,9 \pm 0,04$ & $-2,1 \pm 0,05$ & $+1,4 \pm 0,05$ & 13,3 & 10,0 & 25,0 \\
\hline & $\mathrm{t}=7,14$ & $\mathrm{t}=6,7$ & $\mathrm{t}=7,14$ & & & \\
\hline \multirow{2}{*}{$\begin{array}{c}\text { Період канікул } \\
\text { (2 тижні) }\end{array}$} & $-2,4 \pm 0,06$ & $-2,5 \pm 0,04$ & $-0,9 \pm 0,05$ & 1,43 & 26,6 & 18,7 \\
\hline & $\mathrm{t}=20,0$ & $\mathrm{t}=11,4$ & $\mathrm{t}=18,3$ & & & \\
\hline Через 5 тижнів & $-4,0 \pm 0,05$ & $-3,3 \pm 0,06$ & $-2,0 \pm 0,04$ & 8,75 & 18,6 & 33,3 \\
\hline
\end{tabular}


було зафіксовано після шести тижнів занять (табл. 2).

Наприклад, показник гнучкості на 6-му тижні дорівнював $+0,5 \pm 0,04$ см, на 7-му тижні $+1,4 \pm 0,05$ см і відповідав «середньому рівню» розвитку гнучкості нормативних значень (табл. 2).

Під час аналізу показників гнучкості хлопчиків віком 13 років експериментальної групи № 1 та експериментальної групи № 2 суттєвої зміни в рухливості суглобів хребта не спостерігалося (для 1-7-го тижня).

Зокрема, показник гнучкості в ЕГ 1 дорівнював на першому тижні -3, $0 \pm 0,06 \mathrm{~cm}$, в Е $\Gamma_{2}--2,9 \pm 0,05 \mathrm{~cm}$, а після сьомого тижня $--2,1 \pm 0,03$ см та $-2,9 \pm$ 0,05 см у хлопчиків віком 13 років (табл. 3 ).

В експериментальній групі № 3 хлопчиків віком 13 років зазначено зміни в показниках гнучкості спостерігалося 3 п'ятого тижня занять (показники становили $(-0 \mathrm{~cm},+0,7 \mathrm{~cm},+1,2$ см). Водночас максимальне проявлення гнучкості у хлопчиків 13 років експериментальної групи № 3 залишилося на низькому рівні.

Отже, дослідження, які було проведено впродовж семи тижнів, підтвердили ефективність дворазових і триразових занять на тиждень із розвитку гнучкості у хлопчиків 11 років порівняно 3 одноразовими заняттями.

Динаміка зміни показників рухливості в суглобах засвідчує позитивну тенденцію розвитку гнучкості хлопчиків віком 12-13 років за умови триразових занять на тиждень із застосуванням фізичних вправ.

Для виявлення динаміки змін у показниках гнучкості хлопчиків 11-13 років у заняттях, які були спрямовані на розвиток рухливості суглобів, вправи не застосовувалися протягом наступних семи тижнів.

Порівняльний аналіз отриманих даних показав, що у всіх експериментальних групах хлопчиків від 11 до 13 років спостерігалися вірогідні зміни до погіршення показників гнучкості. Зниження гнучкості в експериментальній групі № 1, експериментальній групі № 2 та експериментальній групі № 3 були неоднаковими за абсолютними показниками й темпами зміни (табл. 1, 2, 3).

В експериментальній групі № 1 за результатами показників гнучкості у хлопчиків, віком від 11 до 13 років, після двох тижнів, потім - після семи тижнів перерви, показники змінювалися то в бік зменшення, то в бік збільшення амплітуди рухів.

Отримані експериментальні дані показують, що після припинення виконання вправ, спрямованих на підвищення рухливості хребта, вірогідне погіршення показників гнучкості спостерігалося в 11-річних хлопчиків експериментальної групи № 2 на 2,9 см, в експериментальній групі № 3 спостерігалися незначні зміни в період канікул і вірогідні зміни в кінці дослідження - $(+1,5 \pm 0,04$ см) проти $(+0,9 \pm 0,05 \mathrm{~cm})(\mathrm{t}=10,0)$ (табл. 1$)$.

У хлопчиків 11 років експериментальної групи № 1 після припинення виконання вправ на заняттях із розвитку гнучкості, після канікул показник знизився на 0,6 cм, а потім - підвищився на 1,3 cм.

Отже, треба зазначити, що показники тестування хлопчиків із розвитку гнучкості експериментальної групи № 1 визначалися переважно природним фактором рухливості в суглобах, а не

Таблиця 3

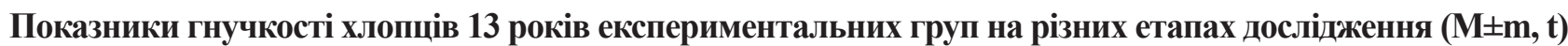

\begin{tabular}{|c|c|c|c|c|c|c|}
\hline \multirow[b]{2}{*}{$\begin{array}{c}\text { Етапи } \\
\text { дослідження }\end{array}$} & \multirow{2}{*}{$\begin{array}{c}\text { Експери- } \\
\text { ментальна } \\
\text { група № } 1 \\
\text { n=8 }\end{array}$} & \multirow{2}{*}{$\begin{array}{c}\text { Експери- } \\
\text { ментальна } \\
\text { група № } 2 \\
\text { n=9 }\end{array}$} & \multirow{2}{*}{$\begin{array}{c}\text { Експери- } \\
\text { ментальна } \\
\text { група № } 3 \\
\text { n=7 }\end{array}$} & \multicolumn{3}{|c|}{ Достовірність розрізнень } \\
\hline & & & & $\mathbf{E} \Gamma_{1} \stackrel{\mathbf{t}_{1}}{-} \mathbf{E} \Gamma_{2}$ & $\mathbf{E} \Gamma_{2}^{\mathbf{t}_{2}}-\mathbf{E} \Gamma_{3}$ & $\mathbf{E} \Gamma_{1}-\mathbf{t} \Gamma_{3}$ \\
\hline \multirow{2}{*}{ Перший тиждень } & $-3,0 \pm 0,06$ & $-2,9 \pm 0,05$ & $-2,8 \pm 0,03$ & 1,25 & 1,66 & 2,85 \\
\hline & $\mathrm{t}=2,86$ & $\mathrm{t}=5,0$ & $t=16,0$ & & & \\
\hline \multirow{2}{*}{ Другий тиждень } & $-2,8 \pm 0,04$ & $-3,3 \pm 0,06$ & $-2,0 \pm 0,04$ & 7,1 & 18,6 & 13,3 \\
\hline & $\mathrm{t}=2,86$ & $\mathrm{t}=1,25$ & $\mathrm{t}=1,67$ & & & \\
\hline \multirow{2}{*}{ Третій тиждень } & $-3,0 \pm 0,06$ & $-3,2 \pm 0,06$ & $-1,9 \pm 0,04$ & 2,5 & 18,5 & 15,7 \\
\hline & $\mathrm{t}=0$ & $\mathrm{t}=1,25$ & $\mathrm{t}=16,7$ & & & \\
\hline \multirow{2}{*}{ Четвертий тиждень } & $-3,0 \pm 0,07$ & $-3,0 \pm 0,05$ & $-2,9 \pm 0,05$ & 0 & 1,43 & 1,11 \\
\hline & $\mathrm{t}=1,25$ & $\mathrm{t}=0$ & $\mathrm{t}=0$ & & & \\
\hline \multirow{2}{*}{ П’ятий тиждень } & $-2,9 \pm 0,04$ & $-3,0 \pm 0,05$ & $0 \pm 0$ & 1,66 & 0 & 0 \\
\hline & $\mathrm{t}=0$ & $\mathrm{t}=15,0$ & $\mathrm{t}=0$ & & & \\
\hline \multirow{2}{*}{ Шостий тиждень } & $-2,9 \pm 0,04$ & $-2,1 \pm 0,04$ & $+0,7 \pm 0,02$ & 13,3 & 35,0 & 55,0 \\
\hline & $\mathrm{t}=2,0$ & $t=8,3$ & $\mathrm{t}=25,0$ & & & \\
\hline \multirow{2}{*}{ Сьомий тиждень } & $-2,1 \pm 0,03$ & $-2,6 \pm 0,05$ & $+1,2 \pm 0,03$ & 3,33 & 23,3 & 40,0 \\
\hline & $\mathrm{t}=11,6$ & $\mathrm{t}=4,17$ & $\mathrm{t}=16,0$ & & & \\
\hline \multirow{2}{*}{$\begin{array}{c}\text { Період канікул } \\
\text { (2 тижні) }\end{array}$} & $-3,5 \pm 0,05$ & $-3,1 \pm 0,11$ & $+0,4 \pm 0,04$ & 3,33 & 22,5 & 51,6 \\
\hline & $\mathrm{t}=6,25$ & $t=7,5$ & $\mathrm{t}=31,7$ & & & \\
\hline Через 5 тижнів & $-3,0 \pm 0,06$ & $-4,0 \pm 0,05$ & $-2,3 \pm 0,05$ & 12,5 & 24,3 & 8,75 \\
\hline
\end{tabular}


ступенем впливу занять. На тиждень одного разу занять не досить для суттєвих змін у розвитку гнучкості.

Аналізуючи динаміку зміни показників гнучкості 12-річних хлопчиків експериментальної групи № 1 та експериментальної групи № 2 спостерігали зниження показників після припинення занять із розвитку рухомості хребта. Зниження показників були вірогідні в обох групах хлопчиків.

Водночас в експериментальній групі № 3 у хлопчиків 12 років після семи тижнів перерви спостерігалося чимале погіршення рухливості в суглобах хребта на 3,4 см. Показники гнучкості хлопчиків в експериментальній групі № 3 iз середнього рівня змінилися на «низький рівень» ( $3+1,4 \pm 0,05$ проти $-2,0 \pm 0,04$ см, $(\mathrm{t}=56,0)$.

Така сама динаміка зміни показників гнучкості після припинення виконання вправ спостерігалась у хлопчиків віком 13 років експериментальної групи № 1 та експериментальної групи № 2 . Вірогідне зниження було виявлено в експериментальній групі № 3 показників рухливості суглобів на 3,5 см $(\mathrm{t}=18,3)$.

Рівень гнучкості протягом усього експерименту залишився у 13-річних хлопчиків на «низькому рівні».

Отже, отримані результати дослідження динаміки змін показників рухливості суглобів у хлопчиків 11-13 років після припинення виконання вправ загалом збігаються 3 даними літератури [9, с. 140].

Виявлено, що після повного (протягом двох місяців) припинення виконання вправ, спрямованих на підвищення рухливості суглобів хребта, стабілізації показників гнучкості не відбулося ні в одній із експериментальних груп.

Водночас рівень гнучкості в 11-річних хлопчиків експериментальної групи № 3 є більш стійким порівняно 3 показниками 12- та 13-річних хлопчиків.
Це можливо зумовлено тим, що вік 11 років $\epsilon$ критичним у розвитку гнучкості і у хлопчиків 11 років експериментальної групи № 3 після повного припинення виконання фізичних вправ на гнучкість збереглися позитивні морфологічні та фізіологічні зміни в м'язовій тканині, які відбувалися в період спрямованого розвитку рухливості суглобів хребта [4, с. 402; 6, с. 84; 9, с. 37].

Можливо, тому, через сім тижнів після припинення занять із розвитку гнучкості природне зниження гнучкості у хлопчиків 11 років в експериментальній групі № 3 не виявило вірогідної негативної динаміки показників (табл. 1).

Висновки. Показники гнучкості експериментальних груп № 2 та № 3 хлопчиків віком 11-13 років, отримані протягом семи тижнів на уроках фізичної культури, підтвердили ефективність дворазових і триразових занять порівняно 3 одноразовими.

Динаміка зміни показників рухливості в суглобах хребта засвідчує позитивну тенденцію розвитку гнучкості в хлопчиків віком 12-13 років за умови триразових занять із застосування спеціальних фізичних вправ.

Після припинення занять, спрямованих на розвиток гнучкості, стабілізації показників рухливості суглобів не відбувалося ні в одній з експериментальних груп, що загалом збігається з даними літератури.

Досягнутий рівень гнучкості 11-річними хлопчиками експериментальної групи № $3 €$ більш стійким, це зумовлено тим, що цей вік $є$ критичним у розвитку гнучкості.

У хлопчиків 11 років в експериментальній групі № 3 не виявлено вірогідної $(\mathrm{t}=1,43)$ негативної динаміки в показниках після припинення занять, спрямованих на розвиток гнучкості.

Перспективи подальших досліджень убачаємо у вивченні показників розвитку і збереження гнучкості в дівчат середнього шкільного віку.

\section{ЛITЕРАТУРА}

1. Ніколаєв Ю., Ніколаєв С. Розвиток гнучкості й рухливості у юнаків середнього та старшого шкільного віку. Фізичне виховання, спорт і культура здоров 'я у сучасному суспільстві. 2013. № 2. С. 86-89.

2. Лях В.И. Гибкость: Основы измерения. Физическая культура в школе. 2003. № 1. С. 29-35.

3. Гужаловский А.А. Развитие двигательных качеств у школьников. Минск : Народна асвета, 2008. $152 \mathrm{c}$.

4. Альтер М.Дж. Наука о гибкости. Киев : Олимпийская литература. 2001. 424 с.

5. Круцевич Т.Ю. Теория и методика физического воспитания. Киев : Олимпийская литература, 2003. T. 1. C. 268-283.

6. Лаврик Н.Г. Темпы снижения гибкости у детей школьного возраста после прекращения занятий, направленных на ее повышение. Материаль международной научно-методической конференции «Фундаментальные и прикладные основы теории физической культуры и теории спорта». Минск : БИФК, 2008. С. 82-85.

7. Платонов В.М., Булатова М.М. Гнучкість спортсмена і методика їі розвитку. Фізична підготовка спортсмена. Київ : Олімпійська література, 2005. С. 276-317.

8. Солдаткина О.М., Борзилова Ж.О. Развитие гибкости в ходе тренировочного процесса. Фізичне виховання, спорт і культура здоров'я у сучасному суспільстві. Луцьк : ВНУ, 2008. Т. 3. С. $333-336$. 
9. Кузьменко І.Ю., Лопата В.Е. Оцінка рівня розвитку гнучкості школярів 12-13 років. Актуальні проблеми фізичного виховання різних верст населення : збірник наукових праць. Харків, 2018. C. 136-143.

\section{REFERENCES}

1. Nikolayev Yu., Nikolayev S. (2013) Rozvytok hnuchkosti y rukhlivosti u yunakiv seredn'oho ta starshoho shkil'noho viku [Development of flexibility and mobility in young men of middle and senior school age]. Physical education, sports and health culture in modern society. № 2. S. 86-89.

2. Lyakh V.I. (2003) Hnuchkist' Osnovy vymiryuvannya [Flexibility: Basics of Measurement] Physical culture at school. № 1. S. 29-35.

3. Huzhalovskyy A.A. (2008) Rozvytok rukhovykh yakostey u shkolyariv [The development of motor skills in schoolchildren]. Mins'k : Narodna asveta. $152 \mathrm{~s}$.

4. Al'ter M.Dzh. (2001) Nauka pro hnuchkist' [Flexibility Science]. Kyyiv : Olimpiys'ka literatura. 424 s.

5. Krutsevych T.Yu. (2003) Teoriya i metodyka fizychnoho vykhovannya [Theory and methodology of physical education]. Kyyiv : Olimpiys'ka literatura. T. 1. S. 268-283.

6. Lavryk N.H. (2008) Tempy znyzhennya hnuchkosti u ditey shkil'noho viku pislya prypynennya zanyat', spryamovanykh na yiyi pidvyshchennya [The rate of decrease in flexibility in school-age children after the termination of classes aimed at increasing it] Materials of the international scientific and methodological conference. Fundamental and applied foundations of the theory of physical culture and theory of sports. Mins'k : BIFK. S. 82-85.

7. Platonov V.M., Bulatova M.M. (2005) Hnuchkist' sportsmena y metodyka ee rozvytku. Fizychna pidhotovka sport smena [Athlete's fatigue i methodology of its development. Physical training of an athlete]. Kyyiv : Olimpiys'ka literatura. S. 276-317.

8. Soldatkyna O.M., Borzylova Zh.O. (2008) Rozvytok hnuchkosti v khodi trenuval'noho protsesu [Development of flexibility during the training process] Physical education, sports and health culture in modern society. Luts'k : VNU. T. 3. S. 333-336.

9. Kuz'menko I.Yu., Lopata V.Ye. (2018) Otsinka urovnya razvytyya hnuchkosti shkolyariv 12-13 rokiv [Assessment of the level of development of flexibility of schoolchildren 12-13 years old] Actual problems of physical education of various segments of the population. Kharkiv. S. 136-143. 